\title{
A autonomia existencial nos atos de disposição do próprio corpo
}

\section{The existential autonomy in the acts of disposition of the own body}

\author{
Maria Celina Bodin de Moraes* \\ Thamis Dalsenter Viveiros de Castro*
}

The body is a big sagacity, a plurality with one sense,

a war and a peace, a flock and a shepherd.

- F. Nietzsche.

\section{Resumo}

A autodeterminação corporal é uma espécie de autonomia existencial que se expressa na liberdade de disposição sobre o corpo ou partes dele. O legislador codicista de 2002, porém, acaba por adotar uma posição paternalista, diametralmente oposta à posição "personalista", compatível com a Constituição. Liberdade, integridade, igualdade e solidariedade, os substratos materiais da dignidade humana, são, portanto, as fronteiras da autonomia corporal, dando fundamentos e limites às concretas disposições sobre o próprio corpo.

Palavras-chave: Dignidade humana. Autonomia existencial. Modificações corporais.

Professora Titular de Direito Civil da Faculdade de Direito da UERJ e professora associada do Departamento de Direito da PUC-Rio. Rio de Janeiro - RJ - Brasil. E-mail: mariacelina.bodin@ terra.com.br

* Doutoranda em Direito Civil pela Universidade do Estado do Rio de Janeiro - UERJ. Possui mestrado em Direito Constitucional e Teoria do Estado pela PUC-Rio (2009), graduação em Direito pela Faculdade de Direito Evandro Lins e Silva - IBMEC (2006). 


\section{Abstract}

Body self-determination is an existential autonomy genre that is expressed in the freedom to dispose of the body or on parts of it. The Civil Code of 2002, however, ends up adopting a paternalistic position diametrically opposed to the position classified as "personalistic" and compatible with the Constitution. Freedom, integrity, equality and solidarity, the material substrates of human dignity are, therefore, the boundaries of bodily autonomy, giving reasons and limits to personal decisions about body modifications.

Keywords: Human dignity. Personal autonomy. Body modification.

\section{Introdução}

"De quem é o corpo? Da pessoa interessada, dos familiares que a cercam, de um Deus que lhe há doado, de uma natureza que o quer inviolável, de um poder social que de mil formas dele se apossa, de um médico ou de um magistrado que estabelecem o seu destino?" (RODOTÀ, 2006, p. 73). Tal indagação é fruto de um grande desconforto porque "corpo" e "pessoa", apesar de sua íntima vinculação, tornaram-se termos cujos conteúdos, tanto concreta como juridicamente, distanciamse cada vez mais.

Trata-se, todavia, de uma realidade complexa, para a qual confluem fatores diversos. A passagem do século XIX para o século $X X$ foi o palco das profundas mudanças que alteraram definitivamente as concepções sobre a pessoa. Surgiu daí a figura do corpo-sujeito, ou seja, de um corpo animado, unidade indissociável entre o físico e o psíquico, entre o espírito e a carne. Antes de tudo, um corpo que é, a um só tempo, ponto de partida e de chegada de um viver singular.

A perspectiva deu ensejo a um contexto jurídico de grandes indefinições. Considerando que o viver singular pressupõe o corpo como um espaço de liberdade, é no Direito que os limites da autonomia corporal formam um dos maiores dilemas jurídicos contemporâneos. De fato, a libertação do corpo animado é um passo avançado no caminho 
que vem sendo trilhado pelo Direito desde que a proteção da pessoa se tornou, no último quartel do século passado, o fundamento de todo o sistema jurídico.

De outro lado, o corpo foi investido de uma extraordinária dimensão político-econômica, a partir da qual as subjetividades foram disciplinadas por um "biopoder", a fim de construir e manter corpos dóceis e úteis aos imperativos do capital. Nesse cenário, de novos poderes, mudam também as verdades e as formas jurídicas. Como observou Foucault, o poder tomou posse da vida e, a partir daí, o Direito deixou de ser o poder de "fazer morrer" e passou a ser o de "fazer viver"1.

No lugar antes ocupado exclusivamente pelo Direito Penal, quando o poder esteve focado no fazer morrer, emerge o Direito Civil como instrumental jurídico ideal de controle dos modos de fazer viver. O biopoder é sustentado juridicamente por uma intensa produção normativa que visa à regulação de todas as etapas do desenvolvimento pessoal nas sociedades de controle.

A "permanente regulamentação" dos modos de "fazer viver", ou da disciplina do cuidado de si, entra em confronto com o livre desenvolvimento da personalidade, constituindo uma complexa relação entre as intervenções jurídicas protetivas e as restritivas. Das falsas dicotomias entre vida, liberdade e dignidade, surge, nesse terreno incerto, o corpo como foco de inúmeras interdições jurídicas pelas quais o desenvolvimento pessoal se distancia de um projeto de realização das escolhas de vida para se tornar um viver de submissão.

\footnotetext{
A análise foucaultiana alerta que essas transformações resultaram na alteração do tradicional direito do soberano, que é o de "fazer morrer [quem desobedece] e deixar viver [quem lhe apraz]", por outro regime, cujas bases estão fixadas no poder de "fazer viver e deixar morrer". Basicamente, o corpo deixa de ser o foco de suplícios penais, pelo que a morte se atrelava ao espetáculo do sofrimento da carne, e passa a ser o feixe de um poder, dito "biopoder", centrado no cuidado do corpo e na disciplina. Num segundo momento, assume a forma de "biopolítica", na qual o enfoque deixa de ser o corpo-indivíduo e passa a ser o corpo-espécie. Surgem a partir daí diversos novos saberes incumbidos de produzir "verdades" e discursos que atendam a tal interesse, permitindo a continuidade dessa biopolítica, tais como a demografia, a análise genealógica, o estudo geracional, a medicina social etc. (FOUCAULT, 2002, p. 286 e segs.).
} 
O capítulo sobre os direitos da personalidade do Código Civil de 2002, além de não dispor de uma cláusula geral, contém tantas medidas restritivas que mais parece cuidar de deveres do que de direitos. A propósito, considerou-se um sério limite do legislador não ter distinguido entre titularidade e exercício, inscrevendo neste o que é atributo daquela. Assim procedeu ao dizer, no art. 11, que "o exercício dos direitos de personalidade não pode sofrer limitação voluntária, quando operou radical inversão, submetendo a pessoa aos direitos, ao invés de pô-los a serviço dela" (VILLELA, 2003, p. 57). Ignorou a multimilenar advertência de Hermogeniano, segundo a qual "todo direito constitui-se em benefício dos homens"2.

Hipótese ainda mais extremada encontra-se no expresso teor do art. 15: "Ninguém pode ser constrangido, com risco de vida, a tratamento médico ou a intervenção cirúrgica.” A propósito, Villela (2003, p. 59) sustenta:

O Código Civil brasileiro, na contramão das tendências autonomistas do direito moderno, afirma a legitimidade da intervenção compulsória sobre o corpo e restringe o exercício da liberdade pessoal. [...] O Código faz da vida matéria de dever. Um dever a que nenhum ser humano pode subtrair-se e que estaria acima de qualquer potestade criada. Terá nisso razão?

Para além das interpretações que podem ser dadas aos dispositivos, é no âmbito dessa tensão entre liberdades e restrições que se insere a análise a ser desenvolvida.

\section{Sujeito e intersubjetividade}

Afirma-se que a autonomia só pode ser compreendida se inserida dentro de uma perspectiva relacional entre subjetividade e intersubjetividade. Sua função não mais se dirige à segurança de

2 D. I, 5, 1: "Hominum causa ius constitutum est", crítica feita também por Villela (2003), ivi. 
uma vontade individual exercida indiscriminadamente ${ }^{3}$. A autonomia, atualmente, cumpre o papel de guiar as relações sociais de tal modo que o reconhecimento recíproco da condição de sujeitos torne possível que a sociedade goze democraticamente de esferas autônomas de desenvolvimento pessoal.

Dessa dimensão intersubjetiva da liberdade, depreende-se a relevância da solidariedade como elemento capaz de realocar o indivíduo no centro do ordenamento jurídico sem, contudo, retomar os passos anteriores que conduziram ao estatuto do indivíduo patrimonial (FACHIN, 2000). A solidariedade é concebida sob duplo viés. O primeiro, da solidariedade objetiva, encontra razão e fundamento na coexistência; enquanto o segundo, da solidariedade como valor, refere-se diretamente à lógica da reciprocidade, ou seja, de respeito à esfera jurídica alheia do mesmo modo que se respeita a própria, em consideração ao sentido de igualdade formal e material (SARMENTO, 2001).

Sobre a solidariedade em equilíbrio com a liberdade para possibilitar a coexistência, ressalta-se a atualidade da perspectiva rousseauniana sobre o amor próprio, o amor de si e a pitié. Essa ponderação faz com que, em associação, não seja inevitável que o amor próprio tome a posição do amor de si. É a pitié, literalmente "pena", que deve ser interpretada como a aversão (repulsa) natural que todo indivíduo não patológico traz em si ao ver outro ser sensível em sofrimento. Esse é o freio do instinto de conservação. Quer dizer, essa é a chave para que não haja um estado de luta de todos contra todos, pois o outro adquire relevância para o eu. A pena, melhor traduzida por compaixão, é capaz, portanto, de conduzir a uma coexistência saudável, pautada pela reciprocidade e pelo reconhecimento do outro como o de um (ROUSSEAU, 1999).

Decorre daí que a as constituições solidaristas do pós-guerra inovaram na tutela das necessidades existenciais, conferindo garantias

Na síntese de Perlingieri (2008), a autonomia privada era vista como autodeterminação, autorregulamentação e poder da vontade. Entretanto, esclarece o autor, por trás do fascínio dessa fórmula estava o liberalismo econômico e a tradução em regras jurídicas das forças mercantis. 
frente ao Estado e aos demais membros da sociedade, sob a rubrica das invioláveis liberdades fundamentais, tais como a liberdade de expressão, a liberdades de crença, as liberdades civis, as liberdades políticas, dentre outras $^{4}$, ao mesmo tempo em que determinaram a solidariedade como código imperativo das relações patrimoniais (PERLINGIERI, 1997).

No plano jurídico nacional, a referida tendência foi consolidada na Constituição Federal de 1988, consoante os moldes constitucionais contemporâneos de absorção dos valores. Concebida sob os anseios de uma sociedade que então se abria para a transição democrática, a Carta Constitucional deu início a uma nova era humanitária, assumindo o compromisso expresso de realização e efetivação da igualdade e liberdade, sendo esta tão cara diante do regime político ditatorial anterior.

Assim, a dignidade da pessoa humana foi assentada na Magna Carta com status de um dos fundamentos da República, ao lado da cidadania, da soberania, do pluralismo político e dos valores sociais do trabalho e da livre iniciativa. Nesse contexto, a dignidade configura-se como cláusula geral de tutela e promoção da personalidade, geradora de deveres positivos e negativos, a qual pressupõe que a pessoa seja concebida a partir de uma reflexão multidisciplinar. Isto é, a dignidade, no papel de princípio unificador do ordenamento jurídico, impõe que o olhar dirigido à pessoa seja capaz de englobar a integralidade do indivíduo, levando-se em conta o contexto social, econômico, cultural e as necessidades físicas e psíquicas de cada sujeito.

De acordo com essa perspectiva, a transformação da dignidade humana em superprincípio ${ }^{5}$ revelou a insuficiência de alguns dos

Estão previstas, por exemplo, no amplo rol de garantias do art. $5^{\circ}$, caput e seus incisos, da Constituição Federal de 1988.

5 Sobre a classificação como superprincípio, Flávia Piovesan (2010a, p. 54 e segs.) aduz que "a dignidade da pessoa humana, [...] está erigida como princípio matriz da Constituição, imprimindoIhe unidade de sentido, condicionando a interpretação das suas normas e revelando-se, ao lado dos Direitos e Garantias Fundamentais, como cânone constitucional que incorpora "as exigências de justiça e dos valores éticos, conferindo suporte axiológico a todo o sistema jurídico brasileiro. [...]. É no valor da dignidade da pessoa humana que a ordem jurídica encontra seu próprio sentido, sendo seu ponto de partida e seu ponto de chegada, na tarefa de interpretação normativa. Consagra-se, assim, a dignidade da pessoa humana como verdadeiro superprincípio a orientar o Direito Internacional e o Interno". 
institutos clássicos do direito privado tradicional, de modo que o conceito de autonomia privada deve ser reformulado para que a força normativa do princípio constitucional incida também sobre as relações jurídicas subjetivas que se desenvolvem no âmbito privado.

Isso porque a produção jurídica dos séculos XVIII e XIX erigiu a patrimonialidade como valor em si, assegurando à autonomia privada patrimonial o lugar de princípio fundamental em um sistema no qual a personalidade era tomada apenas como atributo do indivíduo patrimonial. Fundada no ideal liberal burguês, a concepção tradicional de autonomia privada funcionava como instituto capaz de garantir juridicamente um sistema econômico de circulação de bens e acumulação de riquezas a salvo das ingerências estatais.

A autonomia operava por meio da dicotomia entre o direito público - garantia de uma administração que operava sob reserva de intervenção - e o direito privado - sistema em que "[...] a liberdade do sujeito consistiria justamente em reconhecer à sua vontade o poder de regular situações jurídicas especialmente patrimoniais: ela se torna liberdade econômica que postula a economia de mercado e a livre concorrência" (PERLINGIERI, 2008, p. 339). Reduzida à função de garantia da liberdade negocial, a noção de autonomia esteve, assim, alicerçada na concepção jurídica da personalidade como atributo do sujeito de direito capaz de realizar livremente negócios jurídicos.

Tomada unicamente sob o viés patrimonial, o exercício da autonomia dava-se em razão e na medida da capacidade de movimentação econômica dos sujeitos, de modo a assegurar a base jurídica requerida pelo modelo de produção capitalista. À categoria dos proprietários era reconhecida a vontade como poder absoluto sobre as relações patrimoniais, ao mesmo tempo em que se tornava possível a venda da força de trabalho daqueles que não gozavam da propriedade 
tradicional, mas que possuíam autonomia para negociar o direito sobre $\mathrm{si}^{6}$.

Tratava-se, pois, de uma liberdade ligada não à ideia de pessoa concretamente identificada, mas tão somente à construção abstrata capaz de definir a todos como sujeitos de direito e, por conseguinte, formalmente livres e igualmente possuidores de direitos e deveres. Esse quadro jurídico desprezou a pessoa em sua essência, assegurando somente a dimensão externa, os atributos necessários para o exercício de um papel social previamente definido. Assim, a personalidade jurídica buscava qualificar o sujeito de acordo com as categorias jurídicas que legitimavam a capacidade e a vontade.

O Direito tornou-se cego para as singularidades que tornam o sujeito único em sua existência, a pretexto de combater qualquer tipo de tratamento desigual. Consoante a dinâmica de igualdade formal que orientou a produção jurídica burguesa, a personalidade, tomada apenas como atributo e não como valor em si mesmo, representava o ideal do projeto emancipatório da racionalidade iluminista. Cumpre salientar, dentre as variadas vertentes do insucesso desse projeto moderno, a inapetência da concepção jurídica da pessoa elaborada unicamente sobre as dimensões da igualdade formal e abstrata e da liberdade irrestrita. Como bem se observou, o discurso predominante na construção do direito privado moderno "culminou na racionalidade que fez a dignidade da pessoa ser sobrepujada pelo patrimonialismo e pelo conceitualismo" (FACHIN; PIANOVSKY, 2008).

Nos termos colocados, o sujeito não era considerado em sua singularidade, mas, ao contrário, era igualado na letra da lei, de tal forma que as variáveis que o tornavam singular eram desconhecidas

6 O direito sobre si mesmo ou a propriedade originária, nas palavras de Adam Smith (apud PRATA, 1982, p. 9): "A propriedade que cada homem tem no seu próprio trabalho é a fonte original de toda outra propriedade, e por isso mais sagrada e inviolável. O patrimônio de um homem pobre consiste na força e destreza das suas mãos; e impedi-lo de aplicar a sua força e destreza da maneira que ele acha mais apropriada, sem lesão do seu vizinho, é uma pura violação desta mais sagrada propriedade. É uma intromissão na justa liberdade quer do trabalhador quer daqueles que poderia estar dispostos a empregá-lo." 
e ignoradas pelo Direito. O exercício autônomo da personalidade estabelecia, nesse sentido, que ser pessoa significava tão somente subsumir a existência à norma, adequando-se às diretrizes estabelecidas pela ordem jurídica. E dentro do ideal jurídico burguês, marcadamente patrimonialista, o sujeito juridicamente reconhecido era aquele livre para vender, contratar, comprar e suceder, e não aquele livre para existir de acordo com a dignidade inerente a todos os homens.

Tal esquema desaguou em uma realidade de hiperindividualismo, pois a autonomia da vontade, concebida como código operativo da modernidade, tornou-se algoz da emancipação subjetiva, reificando o sujeito universal moderno nas relações intersubjetivas. O sujeito de direito não foi capaz de reconhecer o outro em condição de reciprocidade; em vez disso, assumiu uma postura predatória que lhe era assegurada juridicamente pela abstração formal da lei burguesa, na qual os valores tutelados passavam ao longe dos laços sociais de solidariedade e fraternidade, restringindo-se à vontade como alicerce de uma ordem social composta, pretensamente, de homens livres e iguais.

Considerando que o sujeito racional solitário está morto (CITTADINO, 2004), vão sendo enterrados aos poucos alguns dos mais importantes postulados que se consagraram como expressões jurídicas do racionalismo moderno, quais sejam: o individualismo, o patrimonialismo e a abstração (FACHIN, 2000). Assim, as transformações jurídicas ocorridas no curso do século $X X$ impuseram a releitura da clássica autonomia para vinculá-la definitivamente à noção de proteção integral da dignidade da pessoa humana.

\section{A dignidade humana em concreto}

As variadas dificuldades encontradas para estabelecer os contornos atuais dos direitos da personalidade, em especial do direito ao próprio corpo, no ordenamento jurídico brasileiro decorrem, principalmente, da substancial alteração sofrida pelo conceito de autonomia privada. Consolidada pela produção jurídica liberal germânica dos séculos XVIII 
e XIX, a autonomia, elaborada segundo a noção de liberdade individual absoluta de cunho patrimonialista, não encontra espaço no Direito Civil contemporâneo. Dentre os muitos motivos de sua atual inadequação, destaca-se a influência da dignidade da pessoa humana como novo paradigma jurídico, a orientar, como é notório, também as relações no âmbito privado (PERLINGIERI, 1997).

Embora seja relativamente recente seu reconhecimento como princípio jurídico, a noção de dignidade humana como valor inerente de cada indivíduo tem origem no ristianismo (BODIN DE MORAES, 2010), de acordo com o postulado de que todos os seres humanos foram criados à imagem e semelhança de Deus. Contudo, foram os processos de racionalização e dessacralização ocorridos durante os séculos XVII e XVIII que possibilitaram a construção kantiana de dignidade fundamentada na autonomia ética do ser humano. (SARLET, 2005). Tratou-se, então, de uma autonomia limitada não só pela proibição externa de coisificação da pessoa, mas também pela determinação de que o próprio homem não pode tratar a si mesmo como objeto.

A dignidade humana estaria, assim, imune às ações de terceiros, bem como de seu titular, de modo que o reconhecimento recíproco da condição de sujeito possa impor um agir considerado racionalmente como regra universal. Os postulados kantianos consolidaram-se com a transformação da dignidade em valor jurídico fundamental e em novo paradigma de tutela da pessoa humana, em virtude das graves crises econômicas que mitigaram a política liberal de não intervencionismo estatal e, principalmente, em razão dos esforços internacionais empreendidos para superação das consequências nefastas das guerras mundiais do século $X X$.

A era hitlerista, lembrada precipuamente pelas atrocidades, torturas e experimentos com seres humanos cometidos durante o regime nazista, que resultaram no extermínio de milhões de pessoas, estabeleceu-se como o nadir das violações aos direitos humanos. Ao cenário mundial do pós-guerra foram impostas, através da mobilização da comunidade internacional, as tarefas de construção de institutos de 
proteção dos direitos humanos e de criação de sistemas referenciais de proteção da pessoa, buscando neutralizar as raízes daquele terrível legado (PIOVESAN, 2000b). Como se sabe, o próprio conceito contemporâneo de "direitos humanos" é um fenômeno do pós-guerra. Seu desenvolvimento é atribuído às violações ocorridas na época e à crença de que parte delas poderia ter sido prevenida se um efetivo sistema de proteção internacional já existisse, o que motivou a mobilização em torno da incipiente "Sociedade das Nações" e de sua transformação na atual Organização das Nações Unidas.

Surgiram, assim, vários instrumentos de proteção, tanto multilaterais como regionais, que acabaram por assentar o caráter universal da dignidade ${ }^{7}$. Uma das mais emblemáticas declarações de direitos humanos, a Declaração Universal da ONU de 1948, consigna em seu artigo $1^{\circ}$ "que todos os seres humanos nascem livres e iguais em dignidade e direitos. Dotados de razão e consciência, devem agir uns para com os outros em espírito e fraternidade". E desde então, a ideia de dignidade, inerente ao ser humano, está presente em grande parte dos diplomas, tratados e convenções ${ }^{8}$, assim como em quase todos os textos constitucionais dos Estados democráticos.

7 Canotilho (1997) observa que é em face das experiências históricas de violação da natureza própria de pessoa, como ocorre nos regimes totalitários, que a dignidade da pessoa humana ganha sentido republicano, ou seja, impõe que o sujeito seja reconhecido como limite e fundamento da República. Além disso, o princípio da dignidade permite assentar a ideia de pluralismo, através de uma configuração constitucional inclusiva, da qual se extrai a harmonia entre o indivíduo e a coletividade através do respeito à diversidade multicultural.

8 Com o mesmo intuito protetivo, houve inúmeras tentativas de regulação ética e jurídica acerca dos limites do progresso científico da biomedicina e da biotecnologia que se desdobraram em diversos diplomas contemporâneos sob essa influência. Por exemplo, as Diretrizes Éticas Internacionais para Pesquisas Biomédicas Envolvendo Seres Humanos, do Conselho para Organizações Internacionais de Ciências Médicas, de 1982; e a Convenção para a Proteção dos Direitos Humanos e da Dignidade do Ser Humano com respeito às Aplicações da Biologia e da Medicina: Convenção sobre Direitos Humanos e Biomedicina do Conselho da Europa, de 1997. Merecem destaque, ainda, a Declaração Ibero-Latino-Americana sobre Ética e Genética (Declaração de Manzanillo de 1996, revisada em 1998); a Declaração Universal da UNESCO sobre o Genoma Humano e os Direitos Humanos, de 1997; as Resoluções n. 196/96 e 303/00 do Conselho Nacional de Saúde, além da Lei de Biossegurança, $\mathrm{n}^{\circ} .11 .105$ de 2005 e suas diretrizes que englobam desde a questão dos transgênicos até a regulamentação das técnicas de reprodução assistida. 
Tais elaborações foram incorporadas à teoria jurídica através das diretrizes adotadas pela Teoria Constitucional, que, após a Segunda Guerra Mundial, inaugurou a construção principiológica como um dos braços fortes de um modelo de Estado Democrático de Direito ${ }^{9}$ alicerçado nos direitos fundamentais. Assim, dentro do novo contexto de estima aos princípios, a dignidade da pessoa humana, antes restrita a indagações de natureza ético-filosófica, passa a ocupar o papel central no debate jurídico contemporâneo, que se concretiza sempre que o Estado o assume como compromisso fundamental (QUEIROZ, 2006).

Consequentemente, grandes esforços foram empenhados para conferir um conteúdo concreto à dignidade, assim como para delimitar seus limites e sua aplicabilidade. Sobre a fixação conceitual, contudo, o único consenso alcançado se faz acerca de sua natureza aberta. Isso porque a dignidade se estabelece, além de por todos os campos do Direito, por todos os âmbitos da vida. Ela informa a ordem jurídica como um todo e, assim, qualquer tentativa positiva de conceituação da dignidade não alcança a pretensão de exaurir as suas possibilidades.

Há casos em que a dignidade é explicitamente desrespeitada, como o registro histórico dos regimes totalitários permite afirmar, sendo o crime de tortura, de escravidão e semelhantes seus mais notórios e frequentes exemplos. Essa relativa facilidade para categorizar condutas que ferem a noção de ser humano, como a medida de todas as coisas, não abarca, contudo, todas as hipóteses de observância do princípio.

Assim, verificar e avaliar a violação em situações tênues - ou porque efetivamente veladas ou porque demandam um juízo por demais subjetivo - torna-se possível a partir da revelação de seus contornos

9 Sobre o modelo adotado, afirma-se: "o Estado Democrático de Direito, tem a característica de ultrapassar não só a formulação do Estado Liberal de Direito, como também a do Estado Social de Direito - vinculado ao Welfare State neocapitalista - impondo à ordem jurídica e à atividade estatal um conteúdo utópico de transformação da realidade. O Estado Democrático de Direito, ao lado do núcleo liberal agregado à questão social, tem como questão fundamental a incorporação efetiva da questão da igualdade como um conteúdo próprio a ser buscado garantir através do asseguramento mínimo de condições mínimas de vida ao cidadão e à comunidade" (STRECK, 2004, p. 37). 
e nuances, se observadas e consideradas no plano concreto, e não a partir da abstração conceitual da norma jurídica. Portanto, a definição de dignidade encontra obstáculos de diversas naturezas e nos mais variados campos do conhecimento, e algumas das maiores dificuldades decorrem principalmente da polissemia e da porosidade do conceito.

$\mathrm{Na}$ tarefa de tentar extrair algum conteúdo material da dignidade, buscou-se analisar o conceito de Kant (2001, p.), relativo à moral, cuja essência podia ser decomposta em nos seguintes postulados:

o sujeito moral reconhece a existência dos outros como sujeitos iguais a ele, merecedores do mesmo respeito à integridade psicofísica de que ele é titular; dotado da vontade livre e parte do grupo social, em relação ao qual tem a garantia de não vir a ser marginalizado.

A partir daí, pareceu possível fornecer um esquema teórico segundo o qual o substrato material da dignidade se desdobra nos princípios jurídicos correspondentes, isto é, na igualdade, na integridade psicofísica, na liberdade e na solidariedade (BODIN DE MORAES, 2010c).

Desta forma, a dignidade transforma-se em uma espécie de "superprincípio"10 a impor proteção plena da pessoa, em todos os seus aspectos, aplicada sempre em concreto. A sua real emancipação não mais ocorre através da garantia de uma liberdade formal de declarar vontade, mas através do que se convencionou chamar de "livre desenvolvimento da personalidade" (SARLET, 2006). Sob esse novo paradigma, é de se destacar que não mais se considera a liberdade em abstrato: toda autonomia é construída a partir da sociedade em

10 Salienta-se que Canotilho (1997, p. 1118) estabelece uma tipologia dos princípios, a saber: os fundamentais, que são historicamente objetivados e progressivamente incorporados na experiência jurídica, cuja recepção se faça expressa ou implicitamente no texto constitucional; há os princípios políticos constitucionalmente conformadores, dos quais se pode inferir as valorações políticas fundamentais do legislador constituinte; há também os princípios constitucionais impositivos, que determinam ao Estado os objetivos que deva perseguir; e finalmente há os princípios-garantia, que tem por objetivo estabelecer de forma direta uma garantia aos cidadãos. 
que se vive ${ }^{11}$, no âmbito da qual a pessoa elabora a sua identidade, na inelutável convivência com o outro (BODIN DE MORAES, 2010).

\section{Da autonomia patrimonial à autonomia existencial}

O Código Civil de 1916, como não poderia deixar de ser, reproduziu o ideal do liberalismo burguês, privilegiando em suas disposições a proteção das relações jurídicas patrimoniais, com particular destaque para as questões relativas à propriedade privada e aos atos de autonomia privada, restando a pessoa humana em posição externa ao objeto de tutela do direito privado, como então devia ser. Tratava-se, portanto, do mesmo sujeito patrimonial, assistido nos limites de sua capacidade para ter e deixado em paz pelo legislador em sua potencialidade para ser.

Tal antropologia jurídica, ou ideologia, que pode também ser definida em termos de um "individualismo possessivo"12 (MACPHERSON, 1975) foi substituída em tempos recentes por uma nova antropologia, consequente à recepção dos valores constitucionais contemporâneos pela cultura jurídica civilista, antropologia que incide sobre o princípio da igualdade de modo especialmente transformador: de fato, "a dignidade humana não depende das circunstâncias externas, a partir de papéis sociais ocupados pelos indivíduos, mas é um valor inerente ao ser humano como tal". (MENGONI, 1985, p. 123).

A opção constituinte de alçar a dignidade humana ao posto de fundamento da República, consoante art. $1^{\circ}$, III, da Constituição de 1998, promoveu a inflexão axiológica que estabeleceu a prevalência das situações existenciais sobre as patrimoniais. No que tange às situações pessoais, portanto, como aquelas que se referem à vida privada do sujeito (liberdade de crença, de associação, de profissão, de pensamento, dentre outras), considera-se haver uma proteção constitucional reforçada, porque, sob o prisma da Constituição, esses

11 A autonomia seria, assim, "o espaço de indeterminação que permite a inventividade, a criatividade das personae que actuam na cena jurídico política" (CANOTILHO, 1995, p. 51).

12 A noção de "individualismo possessivo" foi definida como a noção de que o homem é homem apenas na medida em que é o próprio proprietário; sua humanidade depende de sua liberdade de estabelecer relações contratuais com os outros com base em seu próprio interesse. 
direitos são indispensáveis para a vida humana digna. Significa dizer que as ações humanas que envolvem escolhas de caráter existencial são protegidas de modo mais intenso pela ordem constitucional.

Será lícito afirmar, assim, que a pessoa foi definida a partir do texto constitucional democrático como o vértice da pirâmide normativa, da qual decorre que todo e qualquer campo do Direito, público ou privado, patrimonial ou extrapatrimonial, deverá ser funcionalizado para que seja atingida a finalidade de proteção e promoção da pessoa humana, considerada sob a perspectiva da coexistência, e não só da existência (FACHIN; PIANOVSKY, 2008).

Conclui-se daí que o direito privado não poderia continuar imune às mutações que definiram as novas funções do Direito. $E$ as adequações foram se apresentando, paulatinamente, principalmente a partir da repersonalização ou "despatrimonialização", uma tendência que coloca o personalismo como superação do individualismo que orientou a produção jurídica liberal, em equilíbrio com o patrimonialismo, rompendo com a posição de supremacia antes ocupada por este.

Cumpre ressaltar que despatrimonializar não significa esvaziar a carga valorativa da tutela dos interesses patrimoniais, mas sim funcionalizá-la de modo que sejam asseguradas as condições materiais para o desenvolvimento da personalidade. O perfeito equilíbrio dessa nova equação depende de uma troca essencial de papéis: a patrimonialidade deixa de ser um valor em si mesmo, passando a ser um instrumento para a realização dos interesses pessoais e sociais, de tal maneira que o personalismo assume o lugar de valor fundamental de todo o ordenamento jurídico (PERLINGIERI, 1997) ${ }^{13}$.

13 De acordo com a perspectiva anunciada, merece destaque o voto do Ministro Eros Grau quando defendeu a constitucionalidade da lei capixaba que instituía a meia-entrada para doadores de sangue, em eventos desportivos, e de cultura e lazer que ocorressem em locais públicos, da administração direta e indireta. Assim se pronunciou o Ministro: "Vê-se, para logo, que se não pode reduzir a livre iniciativa, qual consagrada no artigo $1^{\circ}$, IV do texto constitucional, meramente à feição que assume como liberdade econômica ou liberdade de iniciativa econômica [...] o conteúdo da livre iniciativa é bem mais amplo [...] ela é a expressão da liberdade titulada não apenas pela empresa, mas também pelo trabalho [...] a atuação Estatal no campo da atividade econômica pode se dar por indução no sentido de [...] levar os seus destinatários a uma opção econômica de interesse coletivo e social que transcende os limites do querer individual [...]" (ADI 3512. Rel. Min. Eros Grau. Julg. 15.02.2006). 
Diante da nova hierarquia de valores, operou-se, portanto, uma "transformação radical na dogmática do direito civil, estabelecendo uma dicotomia essencial entre as relações jurídicas existenciais e as relações jurídicas patrimoniais" (TEPEDINO, 2003-2004). Essa nova divisio representa, por sua vez, o antídoto para a antiga divisão entre o público e o privado: a necessidade de disciplinas diferenciadas em relação à tutela das liberdades, segundo seu campo de incidência, que sejam capazes de promover a existência ao mesmo tempo em que garantem a coexistência.

Diante disso, a autonomia privada não se identifica com a iniciativa econômica nem com a autonomia contratual em sentido estrito: o contrato, como negócio patrimonial, não exaure a área de relevância da liberdade dos particulares (mas é melhor a esse ponto dizer: a liberdade da pessoa). Ao contrário, não somente ela se exprime também em matérias nas quais diretamente são envolvidas situações subjetivas existenciais, mas, sobretudo, a abordagem do ordenamento não pode ser abstrata quando a autonomia (o poder de estipular regras) investe profundamente o valor da pessoa (PERLINGIERI, 1997).

A autonomia patrimonial é compreendida, dessa forma, como "ato de iniciativa de ao menos uma das partes interessadas na negociação. Realização não apenas de direitos subjetivos, mas também de deveres de solidariedade e, às vezes, de obrigações legais de contratação" (PERLINGIERI, 2008, p. 347), e é permeada pelo caráter hoje fundamental da intervenção estatal, assentado, pois, nos ditames constitucionais de uma ordem jurídica solidarista.

A autonomia privada existencial, por sua vez, seria o instrumento da liberdade que incide precisamente - mas não exclusivamente nas situações jurídicas subjetivas situadas na esfera extrapatrimonial. Do ponto de vista da garantia constitucional, portanto, o conteúdo da liberdade individual, no que se refere às decisões pessoais, é um espaço, uma possibilidade de escolha que pode se expressar de modos variados: é liberdade tanto a possibilidade de realizar tudo o que não é proibido como a exigência de não intervenção na vida privada do 
indivíduo, ou ainda a possibilidade de autodeterminação ou obediência a si mesmo (isto é, ao próprio regulamento). A possibilidade de escolha precisa ser assegurada, seu conteúdo é que deve ser escolhido pelo indivíduo. É como se tratasse de um "espaço vazio" que a lei precisa garantir para que possa vir a ser preenchido individualmente (BODIN DE MORAES, 2010a).

Mas para que seja possível afirmar tutelas diferenciadas de acordo com a natureza da relação jurídica, é preciso estabelecer quais critérios podem ser utilizados para distinguir a patrimonialidade da existencialidade. Tais fronteiras, porém, não são de fácil definição. Todavia, foi efetivada a opção, neste trabalho, por elencar os aspectos principais que, mesmo sem satisfazer à complexidade da questão em si, servem aos propósitos caracterizadores da autodeterminação corporal.

Ao contrário do que a terminologia pode sugerir, não há linhas que inscrevam definitivamente situações jurídicas subjetivas somente no campo existencial ou no patrimonial, fazendo jus somente às nomenclaturas adotadas. Essa dificuldade em encerrar a natureza das situações jurídicas subjetivas, longe de determinar a insuficiência de um esquema diferenciado de proteção, aponta para o rompimento da concepção prioritariamente patrimonialista das relações privadas. Em outras palavras, é preciso buscar na natureza das situações subjetivas qual dimensão é preponderante, de maneira que a configuração de funções existenciais justifique uma incidência normativa capaz de limitar a autonomia com objetivo de tornar concreta a dignidade.

O problema maior do Direito na atualidade tem sido exatamente estabelecer um compromisso aceitável entre os valores fundamentais comuns, capazes de fornecer os enquadramentos éticos nos quais as leis se inspirem, e espaços de liberdade, os mais amplos possíveis, de modo a permitir a cada um a escolha de seus atos e o direcionamento de sua vida particular, de sua trajetória individual.

A autonomia privada existencial, especificamente a autonomia corporal, constitui um elemento novo e central para a configuração jurídica das biopolíticas e da disciplina, de modo que o papel outrora 
ocupado pela vigilância constante passa a ter expressa representação no campo da regulação civil da vida em seu aspecto originariamente mais privado, qual seja, o corpo e, ainda mais, os genes.

Isso porque a configuração atual da privacidade relaciona-se com a esfera privada de diversas formas, ecoando na intimidade, na individualidade e na liberdade, representando muito mais do que o clássico "direito a estar só”, expressão jurídica tipicamente liberal, com vistas à individualização do indivíduo em sociedade. A privacidade, atualmente, diz respeito às escolhas de vida feitas pela pessoa e, nesse sentido, torna-se alvo dos quadros jurídicos estabelecidos por outros, donos do poder. Com isso, a autonomia do indivíduo para definir as bases do caminho a ser trilhado em sua vida deixa de ser fruto da construção voluntária do sujeito.

\section{A autodeterminação corporal entre restrições e liberdades}

A autonomia corporal, entendida como a capacidade de autodeterminação da pessoa em relação ao próprio corpo, está inserida na seara da existencialidade ou extrapatrimonialidade, ou seja, é espécie do gênero "autonomia existencial" antes descrito. Contudo, ela compõe o terreno de atuação concreta da liberdade, que se exprime, originariamente, na esfera de seu titular, não sendo parte necessária de uma relação entre sujeitos, mas sim do sujeito sobre si mesmo.

Até então, somente o Código Penal abordava o corpo como bem jurídico singular, posto a salvo somente de determinadas práticas criminosas lesivas à integridade física. A teoria civilista oitocentista conhecia apenas o sujeito abstrato, cujo corpo era ignorado em sua singularidade. Todavia, tal realidade foi profundamente alterada pelo movimento de repersonalização do Direito Civil, que tem na pessoa o núcleo central de todas as preocupações do Direito (FACHIN; PIANOVSKI, 2008), em decorrência da consagração da dignidade humana como paradigma jurídico, a orientar também as relações no âmbito privado. 
Assim, o corpo passa a figurar no direito privado de forma completamente distinta: de um lado, um corpo que não poderá ser maculado por terceiros, sob pena de reparação dos danos sofridos; de outro, passa a ser protegido, inclusive, das investidas lesivas de seu titular. Isso significa que a integridade psicofísica passa a ser objeto de tutela civil, e não apenas penal, de modo que, se a autolesão não pode sofrer a penalização deverá, por seu turno, ser condicionada aos imperativos protetivos da personalidade na esfera cível.

Esse alargamento da tutela sobre o corpo foi consagrado pelos direitos da personalidade, inexistentes no Código Civil de 1916, mas presentes no Código Civil de 2002 como um rol não taxativo de hipóteses tuteláveis $^{14}$. Dentre elas, encontra-se a disciplina da disposição sobre o próprio corpo, positivada no artigo 13, nos seguintes termos:

Art. 13. Salvo por exigência médica, é defeso o ato de disposição do próprio corpo, quando importar diminuição permanente da integridade física, ou contrariar os bons costumes.

Parágrafo único. $\mathrm{O}$ ato previsto neste artigo será admitido para fins de transplante, na forma estabelecida em lei especial ${ }^{15}$.

Tal postura estatal acaba por deslocar o Direito de uma posição personalista para outra, diametralmente oposta, classificada como paternalista. Nas palavras de Dworkin (2002, p. 156), o paternalismo é uma "interferência na liberdade de ação do indivíduo, justificada por razões que se referem exclusivamente ao bem-estar, ao benefício, à felicidade, às necessidades, aos interesses ou valores da pessoa coagida". Contudo, o paternalismo é gênero do qual decorrem diversas

14 Mal vale a pena lembrar a previsão do Código de 2002 acerca da tutela dos direitos da personalidade, senão para criticá-la. Como reconheceu o autor do projeto da parte geral: "[...] se abriu um capítulo para os direitos da personalidade, estabelecendo-se não uma disciplina completa, mas os seus princípios fundamentais" (ALVES, 1999, p. 1).

15 Enunciado n. 276 do CJF: "O artigo 13 do Código Civil, ao permitir a disposição do próprio corpo por exigência médica, autoriza as cirurgias de transgenitalização, em conformidade com os procedimentos estabelecidos pelo Conselho Federal de Medicina, e a consequente alteração do prenome e do sexo no Registro Civil." 
espécies, como o paternalismo médico, o paternalismo político, o paternalismo benevolente, como expressão da relação entre pais e filhos, e o paternalismo jurídico.

De modo geral, as diversas modalidades podem ser categorizadas de acordo com o fim a que se destinam: algumas delas querem afastar o sujeito despido de autonomia, temporária ou definitivamente, do mal que possa infringi-lo, enquanto outras têm como objetivo promover o bem que o sujeito não possui os mecanismos para reconhecer como seu melhor interesse (PALMER, 2002).

A primeira modalidade, também classificada como paternalismo fraco, incide nas hipóteses em que o mal resulta da falta de escolha ou na falta de conhecimento sobre o potencial lesivo da conduta intentada. É exemplo dessa intervenção paternalista a ação que visa afastar a ameaça de que uma conduta involuntária resulte em situações não benéficas ao sujeito, como impedir que o viciado em alucinógenos se jogue pela janela. Do mesmo modo, o agir paternalista comporta a movimentação que decorre da ignorância sobre o mal em potencial, como impedir alguém de ingerir substância que ignora ser tóxica ou venenosa. Abrange ainda a hipótese em que se julga necessário agir na dúvida sobre a voluntariedade ou não da situação, como tirar uma pessoa da frente de um ônibus mesmo sem saber se ela deseja levar a vida a termo (PALMER, 2002).

A segunda modalidade, chamada de paternalismo forte, admite a intervenção sobre a conduta quando o mal resulta de uma ação voluntária e informada. Essa espécie de paternalismo está usualmente presente nas hipóteses de fraqueza da vontade, quando o sujeito sabe que determinada ação provocará o mal, mas mesmo assim escolhe praticá-la. Ainda que essa escolha seja motivada por razões incontroláveis, o agente possui pleno conhecimento acerca dos males que ela pode acarretar.

O paternalismo forte é tradicionalmente identificado nas políticas públicas como campanhas de combate ao fumo, leis que proíbem o fumo em lugares fechados, leis que determinam índices de consumo 
alcoólico compatíveis com a direção de veículos automotivos, leis que restringem o porte de armas, leis que impõem a vacinação obrigatória e políticas públicas que determinam o controle intenso de doenças. Em tais situações, tem-se uma intervenção estatal legitimada, por um lado, pela proteção da esfera jurídica de terceiros, ou seja, o Estado atua proibindo o fumo em lugares fechados para proteger o não fumante dos riscos do fumo passivo, proíbe a direção da pessoa alcoolizada para não trazer riscos de acidentes na via pública, o porte de armas pode ser restrito face aos perigos que elas representam para a vida de outras pessoas, a vacinação obrigatória é de suma importância para que doenças contagiosas não acarretem epidemias ou pandemias.

Por outro lado, esse tipo de atuação estatal visa à conscientização da população em relação aos efeitos lesivos de tais práticas. Mas essa consequência é buscada de modo residual, vale dizer, o fumante que não pode fumar em recintos fechados acaba fumando menos a criança vacinada não contamina outras crianças e se torna imune à doença, o motorista que não pode dirigir alcoolizado não coloca a vida de outras pessoas nem a sua em risco. De modo geral, portanto, são condutas que causam riscos ao indivíduo e à sociedade.

Frequentemente, as hipóteses que ensejam o paternalismo forte são chamadas de atos acráticos, ou seja, práticas paradoxais em relação à racionalidade. São movimentos voluntários que o sujeito opta por executar mesmo consciente dos males que podem ocorrer, a exemplo do fumante que, mesmo sabendo dos prejuízos causados pelo tabagismo, continua a fumar. Do mesmo modo, os excessos no hábito de beber e comer acarretam consequências nefastas que são consideradas pelos sujeitos, mas não afastadas, de modo que se tornam menores diante do prazer que tais práticas podem proporcionar. Embora o sujeito realmente acredite que queira se livrar daquele hábito, porque sabe que faz mal - efetiva ou potencialmente - à sua saúde, ele, na realidade, não quer renunciar ao prazer que o fumo, por exemplo, lhe traz.

Escolhe então, racionalmente, o que faz mal ao corpo, mas provavelmente bem à alma. Sente o que diz o poeta: 
'Fumar é a forma disfarçada de suspirar'. A curto prazo, na realidade, todos praticamos tais atos. Quantas vezes fazemos o que sabemos que não devemos fazer? Nos enchemos de chocolates, comidas engorduradas, pileques? Mas a curto prazo nenhum problema surge. Com o fumante inveterado, o alcoólatra, o obeso mórbido isso ocorre numerosas vezes por dia, ao longo de muitos anos, e a cada vez ele pode pensar que deveria fazer diversamente. Como não se dispõe, diz-se dependente do cigarro, da bebida ou da comida para viver. (BODIN DE MORAES, 2010a, p.192).

Não raro, a dependência recebe o crédito pela prática de atos acráticos. A vontade se torna fraca diante de fatores que fogem à racionalidade. Assim, justifica-se que o tabagista continue a fumar, porque o cigarro contém substâncias que geram dependência. De maneira idêntica, a obesidade mórbida é explicada em razão de desequilíbrios químicos que geram a compulsão e interditam a vontade.

Por outra parte, são inúmeros os atos ditos irracionais que não derivam de influências externas que causem dependência, como o fato de as Testemunhas de Jeová se recusarem a receber uma transfusão de sangue que sabem ser imprescindível à manutenção de suas vidas ${ }^{16}$, ou ainda as situações em que o paciente depende da amputação de um

16 As Testemunhas de Jeová recusam a transfusão de sangue com base numa interpretação das passagens bíblicas em que a hemoterapia seria proibida pelas Leis Divinas, sendo que a utilização dos hemoderivados já é consentida. Contudo, não raro os Tribunais se pronunciam sobre $\mathrm{o}$ conflito entre o direito à vida e o direito à liberdade de crença. Parece interessante a hipótese concreta apreciada pelo Tribunal de Justiça de Minas Gerais, destacando-se trechos dos argumentos referidos no Acórdão sobre a capacidade de autodeterminação do doente: "É inegável que o objeto da irresignação recursal envolve valores constitucionais que necessitam de avaliação prudente, sob pena de institucionalizar-se uma relação ditatorial entre o Estado e o cidadão que titulariza uma série de prerrogativas consideradas fundamentais pela Constituição da República. Com efeito, a vida humana é um bem jurídico que não pode ser desprezado e é tratado como direito fundamental, mesmo porque precede o exercício de quaisquer outros direitos, haja vista a tutela recebida no âmbito penal. Não há como deixar de reconhecer, em princípio, que associado a este bem, dele deflui a dignidade da pessoa humana, um dos valores que orientam a República (art. $\left.1^{\circ}, \mathrm{III}\right)$. Dentro deste contexto, é preciso considerar que a recusa do agravante em submeter-se à transfusão de sangue é providência legítima desde que não esteja inconsciente e possua condições de externar juízo de valor sobre os procedimentos necessários à conservação de sua vida. (MINAS GERAIS. TJMG. Ag. n 1.0701.07.191519-6/001. Rel. Des. Alberto Vilas Boas, publ.: 04.09.2007). 
de seus membros para ter a vida salva, mas mesmo assim recusa-se a fazer a operação. As Testemunhas de Jeová não se recusam a viver, e certamente possuem padrões de vida que fogem não à moral, mas aos costumes da maioria da população. Trata-se, na verdade, de uma simples consequência da liberdade de consciência, de modo que o sujeito se recusa ao cumprimento daquilo que se reputa tradicionalmente como razoável ou lícito, mas que é incompatível com as suas mais íntimas convicções. Nesse caso específico, ocorre situação em que a pessoa se sente moralmente obrigada a não cumprir com as expectativas coletivas por força de suas convicções de crença religiosa ${ }^{17}$. Tradicionalmente, esse tipo de liberdade de consciência recebe o nome de "objeção de consciência", tema caro aos estudiosos do Direito Penal, como elemento de exclusão da culpabilidade. O paternalismo aqui é reduzido face à garantia de direitos fundamentais, como a liberdade de crença, considerada um dos embasamentos constitucionais desse tipo de autonomia sobre o corpo.

O exemplo da objeção de consciência no caso apresentado é relevante também por outras duas razões: a primeira é a intervenção do Estado na autonomia individual quando são postos em questão os limites relativos a terceiros, e a segunda é sobre a integridade psicofísica como conceito uno e indivisível. De acordo com as restrições da autonomia por razões de consciência, assinala-se que, independentemente da liberdade de escolha e das suas íntimas convicções, o sujeito não pode fazer do exercício de sua autonomia um risco à esfera jurídica de terceiros. Assim, no exemplo apresentado sobre a recusa de tratamento médico de Testemunha de Jeová, convém assinalar que a objeção de consciência $^{18}$ da mãe não é capaz de conferir o corpo do filho como

17 Nesse sentido: "a particularidade da escusa de consciência reside na irresistibilidade, para o agente individual, dos imperativos morais que segue, o que pode provocar situações de conflitos verdadeiramente existenciais, não Ihe deixando margem de ação lícita, senão ao custo de significativo comprometimento de sua personalidade" (HERING JR., 2006, p. 118).

18 De acordo com a lição de R. Soriano (1991, p 45): "La objeción de conciencia es así una forma de la libertad ideológica de la persona, que consiste en la excepción justificada del cumplimento de un deber jurídico colisionante con los dictados de la conciencia individual." 
campo de sua autonomia, de modo que o tratamento médico deverá ser implementado, sob pena de abuso de pátrio poder.

Do mesmo modo, reconhece-se o direito de objeção de consciência de qualquer pessoa a negar a prática do aborto por motivos morais, que em sua maioria refletem convicções religiosas de respeito à vida desde sua forma embrionária, impedindo a atuação do profissional. Todavia, o limite de consciência relativo à esfera de proteção jurídica alheia a do titular da objeção determina que em situações de emergência, quando há risco de vida para a gestante, ou seja, no caso do aborto necessário, a recusa à prática do aborto acarreta em crime de omissão de socorro.

Com efeito, nesses casos, o paternalismo perde espaço para as convicções pessoais não só por se tratarem de hipóteses de exercício da liberdade assegurados constitucionalmente, mas também porque representam situações de conflitos verdadeiramente existenciais. Nessas situações, a observância do dever jurídico de preservação da integridade física (como pressuposto necessário à continuidade da vida) significaria uma violação da ordem psíquica, concluindo-se que esses espaços de liberdade, quando violados, são punidos com os aspectos subjetivos da própria personalidade.

Tem-se, portanto, um importante aspecto a ser considerado. A integridade compõe-se de duas categorias indissociáveis do ser: o corpo e a mente. Nesse sentido, a superação do dualismo cartesiano, consagrado como um dos signos da modernidade, resultou na compreensão de corpo indissociável da dimensão psíquica, de modo que, também no campo jurídico, a integridade deve ser tratada de acordo com a perspectiva da integridade psicofísica.

Assim, as interdições feitas sobre a matéria corporal geram consequências inafastáveis na constituição mental da pessoa. Dessa forma, a autonomia corporal refere-se diretamente à integridade de maneira global, considerando a inseparabilidade das respectivas esferas. As restrições impostas à autodeterminação no tocante ao corpo devem 
atentar para o fato de que, no âmbito do resguardo da dimensão física, estão sempre incluídas objeções que se referem ao plano psíquico.

Cabe ressaltar que, do final do século passado até os dias atuais, o corpo passou por outra profunda alteração: a chamada "fragmentação". O corpo foi decomposto em partes diversas, que assumiram, na ciência contemporânea, sentido próprio. Conservou-se a unicidade na essência, mas fragmentou-se a forma e a matéria em segmentos praticamente estanques que podem ser considerados de maneira individual, sem prejuízo para o todo corporal.

No campo da medicina, as intervenções estéticas reduzem formas e medidas, alteram a constituição primária do nariz, da boca, dos olhos, dos seios, transmutando a natureza e apagando as marcas indesejadas, muitas vezes de forma irreversível. Trata-se de novas configurações corporais, fabricadas e manipuladas em consultórios e centros cirúrgicos, para atingir os novos padrões de desenvolvimento e realização pessoais. Com fins terapêuticos, os progressos da medicina, que no século passado prolongaram a vida através das máquinas que substituíam artificialmente as funções vitais, hoje suprimiram as falhas dos órgãos inservíveis com toda sorte de transplantes, até mesmo de rosto. Esses avanços ocorrem em uma era na qual a singularidade dos corpos é atestada através do reconhecimento das potencialidades genéticas de cada indivíduo (KECK; RABINOW, 2008).

Muito mais do que a busca por um novo nariz, seio ou boca, tratase, na realidade, de uma alteração do eu, tanto de um corpo que se relaciona com o meio externo - uma forma de enquadramento social, portanto - quanto de um corpo que é expressão da singularidade - uma forma de experiência corporal eminentemente subjetiva. É, em suma, a tentativa de incorporar padrões exteriores nos quais se depositam as expectativas de transformações internas. Assim, muitas alterações na constituição física do sujeito podem ser consideradas atuações que diminuem a integridade física, justificadas, no entanto, pelas exigências que vêm de sua dimensão psíquica. 


\section{Modificação corporal: hipóteses e critérios}

As modificações corporais, na verdade, compreendem uma série de atuações sobre o corpo, de matrizes diversas e não somente artísticas, aqui tomadas como produtos culturais, que se referem

a um leque imenso de práticas que inclui: tatuagem, piercings, branding, cutting, implantes subcutâneos ou ICTs etc. Também são formas de modificação corporal o bodybuilding, atividades de fitness e de wellness [...] bem como todo tipo de próteses internas e externas para potencializar ou substituir o funcionamento dos órgãos e o uso cada vez menos distante da nanotecnologia, que promete novos desenvolvimentos no interior do corpo. (ORTEGA, 2008, p. 57).

Veja-se, por exemplo, o que fizeram de Erik Sprague e Dennis Avner, respectivamente, o homem-lagarto e o homem-tigre. As alterações na estrutura corporal original de Erik Sprague, um norte-americano de meia idade, decorreram de mais de setecentas horas de tatuagens, implantes de chifres de teflon inseridos sob a pele das sobrancelhas, a língua partida e dentes lixados que o fizeram celebridade no papel de artista performático, desde 1999, quando abandonou seu doutorado em Filosofia ${ }^{19}$. Dennis Avner, por sua vez, norte-americano descendente de índios huron e lakota, poucos anos mais velho, resolveu seguir de forma literal os aconselhamentos de um chefe huron para "seguir o caminho do tigre". Considerando que seu nome indígena é Stalking Cat ("felino caçador"), Dennis tornou-se adepto da prática body modification, buscando, através de inúmeras tatuagens que reproduzem a estampa da pele dos tigres, implante de fios que se assemelham aos bigodes felinos e aplicação de silicone nos lábios superiores, construir sua imagem à semelhança efetiva de um tigre, tendo alcançado resultados notáveis ${ }^{20}$.

\footnotetext{
19 V. o site oficial em: <http://www.thelizardman.com. V.tb. http://iam.bmezine.com/?The+Lizardman> Acesso em: 20 jul. 2014.

20 Dennis Avner suicidou-se em novembro de 2012. V. <http://news.bme.com/2012/11/12/ripstalking-cat/> Acesso em: 20 jul. 2014.
} 
Do mesmo modo, a artista francesa Orlan, da linha chamada body art, corrente artística que explora os limites do corpo através de performances variadas, criou o "manifesto por uma arte mais carnal" e fez de suas transformações corporais o espetáculo "A reencarnação da Santa Orlan", numa série em que ela se submeteu a nove cirurgias plásticas, transmitidas via satélite para diversos lugares, entre eles, as principais galerias de arte da Europa. Em visita ao Brasil, em agosto de 2008, afirmou que seu corpo havia se tornado um espaço de reflexão, e as cirurgias eram utilizadas para fazer um autorretrato ${ }^{21}$. Segundo ela,

[...] não estou nem aí com as imagens que produzi de mim mesma, porque não fui eu que escolhi o ponto de partida. Não escolhi meu nome, nem a cor da minha pele. Nós somos cidadãos do mundo, receptores de estímulos que vêm dos lugares mais diferentes, da televisão, da internet. Não quero fazer cirurgia todos os dias, prefiro beber champanhe com os meus amigos. Mas seria divertido se pudesse mudar o meu rosto diariamente ${ }^{22}$.

Stelios Arcadiou, 62 anos, conhecido como o artista performático Stelarc, famoso por fazer usos diferenciados de seu corpo com projetos futuristas, como implantar uma terceira orelha em seu antebraço criada em laboratório por cientistas da Universidade Nottingham Trent, busca demonstrar aquilo que considera seu lema: o corpo é obsoleto.23

Ainda considerada por muitos como ficção científica, a tecnologia de informação e comunicação (ICT) tem sido utilizada no corpo humano há bastante tempo. Mais recentemente, implantes humanos de baixa tecnologia têm sido cada vez mais usados em contextos não terapêuticos.

\footnotetext{
21 Noticiado em: <http://www1.folha.uol.com.br/folha/ilustrada/ult90u437443.shtml> Acesso em: 20 set. 2014.

22 Tais informações estão disponíveis em: <http://g1.globo.com/Noticias/PopArte/0,,MUL7363837084,00FRANCESA+ORLAN+FALA+SOBRE+A+ARTE+DE+MODIFICAR+O+PROPRIO+COR PO+COM+CIRURGIAS.html> Acesso em: 20 jul. 2014.

23 <http://news.bbc.co.uk/2/hi/health/7039821.stm> Acesso em: 30 jul. 2014. Site oficial do artista: <http://stelarc.org/_.swf> Acesso em: 25 nov. 2014.
} 
As aplicações incluem entradas em boates VIP, pagamentos automáticos e controle seguro de acesso.

Implantes humanos médicos como marca-passos e implantes cocleares são de uso comum, formando ligações íntimas entre tecnologia e corpo. Tais dispositivos restauradores estão cada vez mais avançados, alguns com interação diretamente com o cérebro e outros quase superando a sua contrapartida natural. Justamente por causa dessa possibilidade, a pessoa passa a ser avaliada em uma nova condição: a condição pós-humana ${ }^{24}$. Por pós-humano entende-se a "possibilidade de integrar ou modificar o organismo também mediante a utilização de instrumentos não humanos ou a substituição de partes do corpo com próteses biônicas, com o objetivo de reintegrar funções perdidas" (DE CICCO, 2013, p. 4).

A utilização das novas tecnologias não deve, claro, ser indiscriminada e deve sobretudo perseguir finalidades merecedoras de tutela. Nos casos de uso terapêutico ou regenerador, não chega a haver controvérsia porque tais mecanismos são avaliados positivamente quando destinados a tutelar o direito fundamental da saúde. Todavia, as implicações jurídicas, éticas e sociais da adoção dessas tecnologias no aprimoramento humano são questões em aberto. A decisão de substituir partes sadias do próprio corpo com componentes biônicos para obter vantagens, especialmente no campo desportivo, continua cercada de incertezas. Assim, apesar de os interessados apelaram por mais segurança jurídica, numerosas lacunas já surgiram entre a realidade comercial dos implantes de aprimoramento e a regulamentação jurídica que falta para regulá-los. Não é de se estranhar que o aumento da comercialização e do potencial de crescimento desses produtos venha gerando debates veementes, mas a melhor sugestão, dado o grau de

24 Sobre esse ponto, v. Rodotà (2008, p. 821 e segs.). Ver também a tese de doutoramento de D. F. SILVA, Do humano ao pós-humano: pessoa e autonomia privada no contexto do aperfeiçoamento biônico, apresentada ao Programa de Pós-Graduação em Direito do Departamento de Direito da PUC-Rio, Rio de Janeiro, maio de 2009. Do mesmo autor, v. Dai diritti umani ai diritti delle persone: riflessioni sulla post-umanità. civilistica.com. Revista eletrônica de direito civil, ano 1 , n. 1, 2012. 
risco, especialmente nos implantes cerebrais, é adotar o princípio da precaução ${ }^{25}$.

Há, também, numerosas práticas realizadas sobre o corpo sem qualquer pretensão artística, como é o caso das suspensões. São atos que jamais devem ser realizados pela pessoa sozinha, devido ao alto risco de ferimentos, choque e outras possibilidades mortais que evidenciam a disposição da integridade física por prazeres que, também gerados no plano corporal, estão ligados diretamente à realização subjetiva. Nesses atos, diversos ganchos de metal são inseridos sob a pele e ligados a um conjunto de roldanas utilizadas para erguer 0 corpo a 30 ou $60 \mathrm{~cm}$ do chão, de modo que a pessoa possa permanecer com seu corpo suspenso enquanto for capaz suportar o próprio peso, a depender de sua vontade a duração do ato ${ }^{26}$.

De modo geral, tais exemplos constituem práticas corporais em que a aparência se torna ao mesmo tempo a essência e, dessa forma, o corpo se revela como um fecundo cenário para a construção de identidades e subjetividades na atualidade, como elemento central para a experiência do eu. Os casos de modificação corporal não partem necessariamente de psicopatologias como as mutilações corporais, mas podem significar um movimento de resistência individual aos disciplinamentos que insistem em identificar os padrões aceitáveis como o corpo natural (ORTEGA, 2008). O corpo assume a autorreflexidade, tornando definitivamente obsoleta não só a clássica separação entre mente e corpo, como também a dicotomia entre exterioridade e interioridade, de modo a se inscrever nos espaços relacionais que fazem com que o sujeito se constitua com e a partir do outro.

Nessas situações de modificação corporal voluntária, trata-se de uma disposição corporal calcada na aptidão para congregar da melhor

25 É o que propõe ERGEN, Y. J. ICT Implants, Nanotechnology, and Some Reasons for Caution. Disponível em: <http://www.bioethics.ac.uk/news/lCT-Implants-nanotechnology-and-somereasons-for-caution.php> Acesso em: 10 out. 2014.

26 Sobre a suspensão corporal, os dados e as imagens mais completos estão na BME Encyclopedia Disponível em:<http://wiki.bme.com/index.php?title=Suspension> AcessO em: 10 out. 2014. 
maneira possível as esferas física e psíquica, ainda que essa tarefa implique redução concreta da primeira para satisfazer aos anseios da segunda, à semelhança do que ocorre na objeção de consciência. Conclui-se daí que o paternalismo como atuação que "promove o bemestar", seja incentivando o bem ou evitando o mal, é incapaz de explicar razoavelmente quais as situações em que a intervenção sobre a autonomia individual é legítima, bem como de tornar claro quais são as pessoas que devem ter suprimido tal direito. Isso porque o paternalismo forte promove intervenções sobre a autonomia sem levar em conta a avaliação subjetiva e objetiva que cada sujeito é capaz de fazer sobre suas próprias condutas e as consequências que deverá suportar.

Na realidade, ordenamentos de tipo paternalista são compatíveis somente com sociedades infantilizadas, tidas como irresponsáveis e inconsequentes, nas quais em regra tudo deve ser proibido ou regulado, podendo-se fazer apenas o que é expressamente permitido - princípio próprio dos sistemas totalitários e, portanto, incompatível com sistemas democráticos. Ao paternalismo, contido na máxima segundo a qual "as pessoas devem ser protegidas de si próprias", deve ser oposta a presunção que vigora nas sociedades democráticas: a liberdade de escolha acerca do próprio destino não pode ser exceção ou, mais simplesmente, a límpida observação de Bobbio (1999, p.458): "O fundamento da forma democrática de governo contraposta às várias formas autocráticas de governo que dominaram grande parte da história do mundo é o reconhecimento da pessoa".

Sob esse prisma, as modificações corporais poderiam ser definidas a priori como contrárias aos mandamentos jurídicos, da mesma maneira que a objeção de consciência não seria apta a afastar a integridade física em nome das razões existenciais implicadas. Certamente, o primeiro grupo de práticas promove uma releitura sobre os limites que nos constituem aparentemente humanos, sendo as razões determinantes para a realização da modificação corporal tão questionáveis quanto as consequências de tais atos. De maneira semelhante, uma visão externa à compartilhada pelas Testemunhas de Jeová é facilmente tomada pela perplexidade de escolhas que fogem ao natural desejo de perseverar 
na existência que comumente levam à afirmação de que a vida é o bem mais valioso e inviolável, sobre o qual nem mesmo a própria pessoa pode ponderar.

A esse respeito, há aspectos importantes que devem ser problematizados, como a amplitude da tutela jurídica dos valores que orientam o agir individual. Não há como sustentar que todo e qualquer valor deve ser considerado digno de proteção pelo Direito, mesmo - e principalmente - dentro de uma sociedade alicerçada em um modelo de democracia pluralista. Assim, a legitimidade jurídica das convicções íntimas estará atrelada ao reconhecimento que a Constituição é capaz de dar sobre esse conteúdo valorativo. Trata-se, com efeito, de um campo de fortes controvérsias, sobre o qual cumpre abordar apenas o necessário para estabelecer os limites intransponíveis traçados no texto constitucional.

A primeira delas se refere à capacidade que o sujeito possui para tornar válida a sua vontade, ou seja, cuida-se da aptidão jurídica para exercer em nome próprio os atos de autonomia relativos ao corpo. Já a segunda noção está presente na impossibilidade de, ainda que o sujeito seja capaz para realizar os atos da vida civil, investir o corpo de uma dimensão mercantilizada ou, em outras palavras, ainda que o querer seja juridicamente válido, não poderá o sujeito tratá-lo como coisa, como algo que tem preço.

A capacidade está intimamente ligada ao discernimento, ou seja, à possibilidade de entender e querer. Com efeito, o discernimento é concebido em escalas, de modo que aquele que o possui por completo será capaz, enquanto aquele que tem o discernimento reduzido será relativamente incapaz e aquele completamente despido de discernimento será absolutamente incapaz. Desse modo, aqueles que sofrem de debilidade mental grave não possuem discernimento para definir os rumos da própria vida, tampouco podem assumir a responsabilidade das suas decisões.

Nesses casos, cumpre ao Direito a tarefa de proteger o ser humano da própria incapacidade, uma vez que lhe falta a aptidão para 
assimilar e avaliar as informações necessárias. O discernimento, ou a capacidade de compreensão e análise, provém de uma característica da condição humana, se não a mais importante, a que melhor define a nossa espécie: a racionalidade. Como seres racionais, a não ser por circunstâncias excepcionais - tais como as mencionadas -, somos "capazes" de raciocinar, refletir, decidir, enfim, de fazer nossas escolhas. Quando temos discernimento, temos autonomia para decidir o que queremos.

A capacidade está ligada a outra noção de igual importância: a responsabilidade. A pessoa capaz de discernir será responsável pelas suas escolhas, devendo suportar e assumir as consequências negativas que porventura venham a ocorrer. Dessa forma, os sujeitos privados de capacidade não serão responsabilizados diretamente pelos danos oriundos de seus atos, os quais deverão ser imputados à figura do curador. Importa salientar que todo agente capaz de discernir será responsável pelos seus atos e, desse modo, sua manifestação de vontade será legítima e salvaguardada pelo Direito, nos limites de sua esfera de atuação.

A capacidade tratada pelo Código Civil é de viés puramente subjetivo. Nesse sentido, as limitações à autodeterminação corporal devem observar também a aptidão da pessoa para definir as diretrizes relativas ao corpo como uma das esferas mais íntimas da subjetividade. Assim, as vedações que têm como base uma imaturidade genérica para gerir tais espaços de liberdade inscrevem-se sob a rubrica de mecanismos paternalistas implementados de forma abstrata e universal pelo legislador ordinário, como acontece no caso do Código Civil.

Todavia, há situações em que a vontade do sujeito capaz não só é insuficiente para constituir o exercício da autodeterminação corporal como deve ser afastada, sob todas as hipóteses, dos regimes das liberdades individuais juridicamente tuteladas. É o caso, por exemplo, da mercantilização do corpo ou de partes dele, seja com o objetivo flagrante de obter lucro com a prática comercial, seja com a utilização do corpo para garantia do próprio sustento. Em tais casos, as formas 
de intervencionismo estatal não são tomadas pelas características negativas tradicionalmente imputadas ao paternalismo jurídico; elas devem ser reverenciadas como mecanismos de garantia para a efetivação da autonomia existencial.

Observe-se que, nessas situações, a capacidade do sujeito é aspecto irrelevante, pois o limite legítimo à autodeterminação se dá não só pela natureza res extra commercium do corpo humano, mas principalmente pelos imperativos de solidariedade que garantem sua dimensão social a salvo das práticas predatórias de mercado ${ }^{27}$.

A solidariedade constitui uma importante fronteira à autodeterminação corporal, ainda mais quando a projeção social do corpo se dá nas sociedades contemporâneas, com mecanismos de poder que se relacionam através de uma lógica empresarial, própria das sociedades de controle. A solidariedade objetiva decorre da necessidade imprescindível da coexistência, e a solidariedade como valor deriva da consciência racional dos interesses em comum. Além destes sentidos, a solidariedade também tem significado de virtude ético-teologal e de necessidade pragmática para que possa ser obtido um resultado prático favorável a quem atue de forma solidária. Em resumo, a solidariedade assume vários contornos, quer como um fato social, quer como virtude ética, ou como resultado de uma escolha pessoal que pode ser movida pela boa-fé, ou por motivos pragmáticos, mas, do ponto de vista jurídico, a solidariedade está inscrita em princípio constitucional moldado para que todos alcancem o objetivo de igual dignidade social.

Portanto, as mutações das técnicas disciplinares e das biopolíticas no capitalismo pós-industrial revelam que cabe ao Direito instituir os obstáculos essenciais para que a sociabilidade não se converta em tendência de expropriação ou apropriação do corpo a caminho de uma

27 Para Rodotà (2006, p. 54), "rechaçar o paternalismo do legislador, afirmando que ele não deveria substituir-se à vontade de quem decide vender um rim para buscar melhores condições de vida para si ou para outros, significa encarcerar ainda mais ferozmente cada um nas dificuldades da própria existência, sem esperança de resgate além daquela que o obriga a perder, junto com partes do corpo, o respeito a si mesmo, em uma situação de total abandono social". 
forma de canibalismo como código operativo das relações intersubjetivas (RODOTÀ, 2006).

\section{Conclusão}

Note-se que as experiências corporais solidárias assumiram, portanto, uma intensa função agregadora do espaço social. As relações sociais, nessa lógica, são reforçadas pelos programas e campanhas governamentais da maioria de países ocidentais como grandes e importantes instrumentos de laços comunitários essenciais às diretrizes de saúde pública. Os doadores anônimos de sangue e de medula óssea retratam fielmente os laços comunitários que podem ser estabelecidos pela lógica da reciprocidade, do mesmo modo que a doação de órgãos ${ }^{28}$ post mortem revela uma compreensão do corpo essencialmente voltada para uma transmissão existencial, como um legado biológico fraterno, para fins altruísticos ou científicos ${ }^{29}$.

Mas o exercício da autonomia corporal não encontra espaço em um Estado que dá conteúdo excessivo ao que é bom e que reconhece apenas retoricamente a capacidade crítica e liberdade de escolha de seus partícipes. Por isso é preciso refutar a lógica de um Estado paternalista que pretende tomar decisões por seus filhos - sempre incapazes de reconhecer o que é o melhor - em busca de um Estado

28 A Associação Brasileira de Transplantes de Órgãos (ABTO) relata um constante, embora ainda insuficiente, aumento no número de doadores de órgãos, especialmente a partir de 2013, como se verifica no relatório disponível em: <http://www.abto.org.br/abtov03/Upload/file/RBT/2014/ rbt3-trim-parc.pdf> Acesso em: 10.11.2014.

29 É igualmente crescente o número de pessoas que doam integralmente os cadáveres para fins científicos em pesquisas realizadas por universidades brasileiras, superando a reverência religiosa que tradicionalmente reveste os rituais de culto aos corpos mortos. A Espanha tornouse o quarto país do mundo em número de doadores de corpo para pesquisa após a morte, As razões, contudo, parecem não ser estritamente solidárias. A comunidade espanhola vem aderindo a essa prática para evitar as despesas funerárias. Disponível em: <http://www.portugues.rfi.fr/ geral/20130109-espanhois-aumentam-doacoes-de-corpos-para-evitar-despesas-com-enterro> Acesso em: 15 nov. 2014. 
que reconheça a liberdade e autonomia de seus representados, tendo como objetivo inafastável a realização dos mais diversos projetos de vida que certamente surgirão.

Liberdade e solidariedade representam os dois lados constitutivos da autonomia corporal. Ambos, contudo, fundamentam e ao mesmo tempo limitam a concreta disposição sobre o corpo. Trata-se de princípios que orientam a autonomia no sentido de inscrevê-la para além da dimensão unicamente individual, sem esvaziá-la a partir de uma perspectiva puramente coletivista. A abordagem focada nas questões da liberdade, problematizadas sob o enfoque do paternalismo e da capacidade, é complementada pelas diretrizes solidárias constitucionalmente estabelecidas na proibição de comércio do corpo ou de partes dele, a despeito de manifestação de vontade legítima do sujeito.

A interpretação do artigo 13 impõe que a indisponibilidade mencionada pelo artigo 11 do Código Civil seja compreendida à luz do direito à privacidade, consagrado pelo artigo 21 do mesmo diploma legal, de modo que, em relação às intervenções jurídicas restritivas da autonomia corporal, a liberdade seja sempre pressuposto inafastável. Dessa maneira, a imposição generalizante de que os direitos da personalidade são indisponíveis, não importando para tanto circunstâncias subjetivas ou objetivas, é relativizada para que o desenvolvimento da personalidade seja um espaço de viver livre e criativo, ou seja, um campo em que as escolhas de vida feitas pela pessoa são protegidas pela privacidade.

O direito ao próprio corpo, expressão da dignidade humana como cláusula geral de tutela e promoção da pessoa, não define por si as fronteiras intransponíveis da autonomia corporal. A adequada interpretação do mencionado art. 13 implica a ponderação dos interesses contrapostos que são revelados no caso concreto, sendo certo que a verdadeira harmonia entre eles somente é alcançada através do princípio da dignidade humana, este sim o único limite que jamais pode ser superado na legalidade constitucional. 


\section{Referências}

ALVES, José Carlos Moreira. A parte geral do projeto do Código Civil. Disponível em: <http://www2.cjf.jus.br/ojs2/index.php/revcej/article/ view/ 231/393> Acesso em: 10 nov. 2014.

ANDRADE, Daniela Dorneles de. On norms and bodies: Findings from field research on cosmetic surgery in Rio de Janeiro, Brazil (June 2010). Reproductive Health Matters, v. 18, n. 35, p. 74-83, may 2010.

BAUMAN, Zygmunt. A sociedade individualizada: vidas contadas e histórias vividas. Rio de Janeiro: Jorge Zahar, 2008.

BERLINGUER, Giovanni. Corpo humano: mercadoria ou valor? Estudos avançados, São Paulo, v.7, n. 19, p. 167-192, dez.1993.

BITTAR, Carlos Alberto. Os direitos da personalidade. Rio de Janeiro: Forense, 2008.

BOBBIO, Norberto. Teoria generale della politica. Torino: Giappichelli, 1999.

BODIN DE MORAES, Maria Celina. Ampliando os direitos da personalidade. In: VIEIRA, José Ribas (Org.). 20 anos da constituição cidadã de 1988: efetivação ou impasse institucional. Rio de Janeiro: Forense, 2008. p.369-388.

. Danos à pessoa humana. Uma leitura civil-constitucional do dano moral. Rio de Janeiro: Renovar, 2004.

. Uma aplicação do princípio da liberdade. In: BODIN DE MORAES, Maria Celina. Na medida da pessoa humana. Rio de Janeiro: Renovar, 2010a. p. 183-206.

. O princípio da dignidade da pessoa humana. In: BODIN DE MORAES, Maria Celina. Na medida da pessoa humana. Rio de Janeiro: Renovar, 2010b. p. 71-120.

. O princípio da solidariedade. In: BODIN DE MORAES, Maria Celina. Na medida da pessoa humana. Rio de Janeiro: Renovar, 2010c. p. 237-265. 
SARLET, Ingo W. (Org.). Constituição, direitos fundamentais e direito privado. Porto Alegre: Livraria do Advogado, 2003.

CANOTILHO, J. J. Gomes. Direito constitucional. Coimbra: Almedina, 1995.

- Direito constitucional e teoria da constituição. 4.ed. Coimbra: Almedina, 1997.

CITTADINO, Gisele. Pluralismo, direito e justiça distributiva: elementos da filosofia constitucional contemporânea. 3.ed. Rio de Janeiro: Lumen Juris, 2004.

COURTINE, Jean-Jacques. História do corpo: as mutações do olhar. O século XX. Petrópolis: Vozes, 2008.

DE CICCO, Maria Cristina. Atos de disposição do próprio corpo entre autonomia e dignidade da pessoa humana. Civilistica.com: Revista eletrônica de direito civil, Rio de Janeiro, ano 2, n. 2, p.1-12, 2013. Disponível em: <http://civilistica.com/atos-de-disposicao-do-propriocorpo/>. Acesso em: 14 jul. 2014

DWORKIN, Ronald. Levando os direitos a sério. São Paulo: Martins Fontes, 2002.

ELIAS, Norbert. A sociedade dos indivíduos. Rio de Janeiro: Jorge Zahar, 1994.

ERGEN, Y. J. ICT Implants, nanotechnology, and some reasons for caution. Disponível em: <http://www.bioethics.ac.uk/news/ICTImplants-nanotechnology-and-some-reasons-for-caution.php> Acesso em: 10 out. 2014.

FACHIN, Luiz Edson. Teoria crítica do direito civil. Rio de Janeiro: Renovar, 2000.

. PIANOVSKI, Carlos Eduardo. A dignidade da pessoa humana no direito contemporâneo: uma crítica da raiz dogmática do neopositivismo constitucionalista. Revista Trimestral de Direito Civil, Rio de Janeiro, v. 35, p.101-119, 2008. 
FOUCAULT, Michel. Em defesa da sociedade. São Paulo: Martins Fontes, 2002.

KANT, Immanuel. Crítica da razão prática. São Paulo: Martins Fontes, 2001.

HERINGER JÚNIOR, Bruno. Objeção de consciência e direito penal. Justificação e Limites. Rio de Janeiro: Lumen Juris, 2006.

KECK, Frédéric; RABINOW, Paul. Invenção e representação do corpo genético. In: COURTINE, Jean-Jacques (Coord.). História do corpo: as mutações do olhar. O século XX. Petrópolis: Vozes, 2008.

MACPHERSON, C. B. The political theory of possessive individualism: Hobbes to Locke. Oxford: Oxford University Press, 1975.

MENGONI, Luigi. Diritto e valori. Bologna: II Mulino, 1985.

MONDARDO, Marcos Leandro. O corpo enquanto "primeiro" território de dominação. O biopoder e a sociedade de controle. Disponível em: <http://www.bocc.uff.br/pag/mondardo-marcos-o-corpo.pdf>. Acesso em: 24 nov. 2014.

MOULIN, Anne Marie. O corpo diante da medicina. In: COURTINE, JeanJacques. (Org.). História do corpo: as mutações do olhar. O século XX. Petrópolis: Vozes, 2008. p. 15-82.

ORTEGA, Francisco. O corpo incerto: corporeidade, tecnologias médicas e cultura contemporânea. Rio de Janeiro: Garamond, 2008.

PALMER, Michel. Problemas morais em medicina. São Paulo: Centro Universitário São Camilo, 2002.

PERLINGIERI, Pietro. O direito civil na legalidade constitucional. Rio de Janeiro: Renovar, 2008.

. Perfis do direito civil. Introdução ao direito civil constitucional. Rio de Janeiro: Renovar, 1997.

PHILLIPS, K.; MCELROY, S.; HUDSON, J.; POPE, H. Body dismorphic disorder: An obsessive-compulsive spectrum disorder, a form of affective 
spectrum disorder, or both? Journal Clinical Psychiatric, Memphis, v. 56, suppl. 4, p.41-50, 1995.

PIOVESAN, Flávia. Direitos humanos e o direito constitucional internacional. 4.ed. São Paulo: Max Limonad, 2000a.

- Introdução ao sistema interamericano de proteção dos direitos humanos: a convenção americana de direitos humanos. In: GOMES, Luiz Flávio; PIOVESAN, Flávia (Coord.). O sistema interamericano de proteção dos direitos humanos e o direito brasileiro. São Paulo: Revista dos Tribunais, 2000b.

PRATA, Ana. A tutela constitucional da autonomia privada. Coimbra: Almedina, 1982.

QUEIROZ, Cristina. Direitos fundamentais sociais: funções, âmbito, conteúdo, questões interpretativas e problemas de justiciabilidade. Coimbra: Ed. Coimbra, 2006.

RABINOW, Paul. Invenção e representação do corpo genético. In: COURTINE, J-J, (Org.). História do corpo: as mutações do olhar. O século XX. Petrópolis: Vozes, 2008. p.83-108.

RODOTÀ, Stefano. Il corpo e il post umano: studi in onore di Davide Messinetti. Napoli: ESI, 2008.

RODOTÀ, Stefano. La vita e le regole: tra diritto e non diritto. Milano: Feltrinelli, 2006.

ROUSSEAU, Jean-Jacques. Emílio ou da Educação. São Paulo: Martins Fontes, 1999.

SARLET, Ingo Wolfgang (Org.). Constituição, direitos fundamentais e direito privado. 2. ed. Porto Alegre: Livraria do Advogado, 2006.

- Dignidade da pessoa humana e direitos fundamentais. Porto Alegre: Livraria do Advogado, 2001.

- Dimensões da dignidade: ensaios de filosofia do direito e direito constitucional. Porto Alegre: Livraria do Advogado, 2005. 
SARMENTO, Daniel. Direitos fundamentais e relações privadas. Rio de Janeiro: Lumen Juris, 2004.

SILVA, Denis Franco. Dai diritti umani ai diritti delle persone: riflessioni sulla post-umanità. civilistica.com.: revista eletrônica de direito civil, v. 1, n. 1, p.1-13, 2012. Disponível em: <http://civilistica.com/dai-dirittiumani/>. Acesso em: 16 ago. 2014.

SORIANO, Ramón. La desobediencia civil. Barcelona: PPU, 1991.

STRECK, Lenio Luiz. Hermenêutica jurídica e(m) crise. Porto Alegre: Livraria do Advogado, 2004.

TEPEDINO, Gustavo. A tutela da personalidade no ordenamento civilconstitucional brasileiro. In: TEPEDINO, Gustavo. Temas de Direito Civil. Rio de Janeiro: Renovar, 2004.

. Crise de fontes normativas e técnica legislativa na parte geral do Código Civil de 2002. In: TEPEDINO, Gustavo (Coord.). A parte geral do novo Código Civil: estudos na perspectiva civil-constitucional. 2. ed. Rio de Janeiro: Renovar, 2003.

TITTMUS, Richard. The gift relationship: from human blood to social policy. London: The New Press, 1997.

VILLELA, João Baptista. Direitos da personalidade negativos: por que não? TABULA: Revista da Faculdade de Direito da UFJF, Juiz de Fora, v. 21, n. 1, p. 9-12, 2004.

. O novo código civil brasileiro e o direito à recusa de tratamento médico. Atti del Congresso internazionale "Il nuovo codice civile del Brasile e il sistema giuridico latinoamericano". Roma e America: Diritto Romano Comune. Modena, n. 16, 2003. p. 55-64.

Recebido em:16/12/14

Aprovado em: 23/12/14 